Volume 6

Number 4 Student Articles Edition

Article 4

2020

\title{
New Challenges to Transboundary Unitization in the Gulf of Mexico
}

Isaac Olson

Texas A\&M University School of Law (Student), isaac.olson.ph@gmail.com

Follow this and additional works at: https://scholarship.law.tamu.edu/journal-of-property-law

Part of the Oil, Gas, and Mineral Law Commons, and the Property Law and Real Estate Commons

\section{Recommended Citation}

Isaac Olson, New Challenges to Transboundary Unitization in the Gulf of Mexico, 6 Tex. A\&M J. Prop. L. 85 (2020).

This Student Article is brought to you for free and open access by Texas A\&M Law Scholarship. It has been accepted for inclusion in Texas A\&M Journal of Property Law by an authorized editor of Texas A\&M Law Scholarship. For more information, please contact aretteen@law.tamu.edu. 


\title{
NeW Challenges to Transboundary Unitization IN THE GULF OF MEXICO
}

\author{
By: Isaac Olson ${ }^{\dagger}$
}

\begin{abstract}
In the last two decades, the search for untapped oil reserves led to many innovations in oil and gas exploration. As new technology continues to open new horizons, oil companies are increasingly able to drill at deeper ocean depths to tap offshore reserves. Offshore drilling poses problems where oil reserves hundreds of miles from shore cross an international boundary line. While American courts typically apply the rule of capture to determine who owns the subsoil resources, international law requires countries to work together to maximize the efficient, safe extraction of the resources. In 2012, the United States and Mexico drafted a treaty that would govern the unitization of an offshore transboundary oil field. Today, Mexico's energy laws are very different. A new administration threatens to unravel recent liberal reforms, and the United States has become more hostile to Chinese investment in the region. With these political challenges in mind, the treaty is very vague on critical issues, particularly its dispute resolution clause, which the United States and Mexico must strengthen if the treaty is to be effective and shared transboundary resources develop efficiently to the benefit of both nations. The treaty creates a body called the Joint Commission to create much of the treaty's policy and procedure. In order to maintain good relations and a healthy energy sector, the Joint Commission needs to create subsidiary committees subject to its control and comprised of various experts to ensure the treaty is implemented impartially.
\end{abstract}

DOI: https://doi.org/10.37419/JPL.V6.I4.4

\footnotetext{
${ }^{\dagger}$ Isaac Olson is a J.D. Candidate at Texas A\&M School of Law. He graduated Summa Cum Laude from Texas Wesleyan University, and is interested in navigating post-liberal international relations and geopolitics. Isaac would like to thank Professor Guillermo Garcia-Sanchez for his invaluable time, feedback, advice, and support.
} 


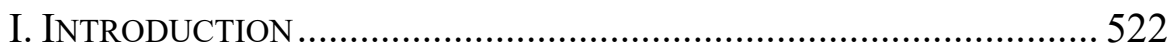

II. HISTORICAL BACKGROUND OF THE 2012 TREATY ........................ 525

A. Mexico's Pre-Reform Hydrocarbon Regime..................... 525

B. Ratification and Energy Reform ................................ 528

1. Relevance of the Treaty Post-Reform ...................... 528

2. Ambiguities and Their Political Impact ..................... 530

III. Potential DiSPUTES \& RESOLUTION ....................................... 532

A. The Rule of Capture and International Law.................. 532

B. Points of Contention ..................................................... 534

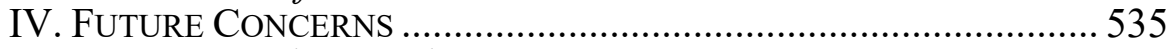

A. Strengthening the Joint Commission ............................. 535

B. AMLO, USMCA, \& Geopolitics................................... 542

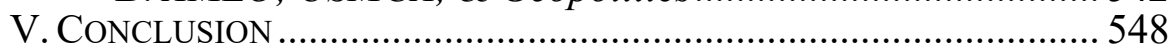

Et quidem naturali iure communia sunt omnium haec: aer et aqua profluens et mare et per hoc litora maris. ${ }^{1}$

- Justinian I

\section{INTRODUCTION}

Roman law regarded the sea as the property of all mankind for all to pass through uninhibited according to Natural Law. ${ }^{2}$ Disputes over trade, the Declaration of Pope Alexander, and Portuguese claims to sovereignty over maritime trade routes led Hugo Grotius to argue from Natural Law that it is impossible to make the sea property, and therefore it should be shared by all nations. ${ }^{3}$ However, by the early modern era, coastal states asserted territorial sovereignty over three miles from the shore - because this is how far the average cannonball from a sea-fort would reach. ${ }^{4}$ This projection of force was the only

1. J. InST. 2.1.1. (Peter Birks \& Grant McLeod trans., Cornell Univ. Press 4th prtg. 1996) ("The things which are naturally everybody's are: air, flowing water, the sea, and the sea-shore.").

2. William T. Abel, Fishing for an International Norm to Govern Straddling Stocks: The Canada-Spain Dispute of 1995, 27 U. MiAmi InTER-AM. L. REV. 553, 556 (1996).

3.Hugo Grotius, Mare Lierum 47 (Ralph van Deman Magoffin trans., Oxford Univ. Press 1916) (1608) ("For it is impossible to acquire by usucaption or prescription things which cannot become property, that is, which are not susceptible of possession or of quasi-possession, and which cannot be alienated. All of which is true with respect to the sea and its use."), available at https://books.google.com/books/about/Mare_liberum.html?id=7SkRAAAAYAAJ $\&$ printsec $=$ frontcover\&source $=\mathrm{kp}$ read_button $\# \mathrm{v}=$ onepage \&q\&f=false.

4. ERnest E. SMith et Al., InTERN̄ATIONAL PETROLEUM TRANSACTIONS 106 (3d ed. 2010). 
way to assert dominion over the waters, and thus the sea was regarded as common property.

As the technology to extract more resources from the world's oceans developed in the 20th century, states began to claim more sovereignty over the oceans to preserve their interest in subsoil resources. ${ }^{5}$ In 1945, President Truman, through federal proclamation, claimed the exclusive federal right to all subsoil resources of the continental shelf adjacent to the territorial sea. ${ }^{6}$ Not wanting to be left out, coastal nations began to claim the continental shelf and all resources therein, leading to maritime boundary disputes the International Community had to settle throughout subsequent decades. $^{7}$

Today, nations with an ocean coastline have different levels of legal jurisdictions within their sovereignty. ${ }^{8}$ Most legal authority establishing the law of the sea comes from the United Nations Convention on the Law of the Sea ("UNCLOS"). ${ }^{9}$ Ratified by most nations, the United States never ratified the convention but has recognized most of it as customary international law. ${ }^{10}$ The convention established jurisdictions including a twelve-mile territorial sea, twenty-four miles of contiguous sea, the 200-mile Exclusive Economic Zone ("EEZ"), and the Continental Shelf. ${ }^{11}$ The modern law of the sea gives all nations the freedom to travel the high seas, including the territorial sea but reserves different rights to ocean and seabed resources in different regions. ${ }^{12}$

Under UNCLOS, states have sovereign rights to all resources in the 200 mile EEZ, including subsoil resources. ${ }^{13}$ Where the continental shelf extends past the EEZ, States can claim up to 350 miles, depending on geological features, and assert sovereignty over subsoil resources in this zone. ${ }^{14}$ UNCLOS leaves the limitation of boundaries

5. Id. at $106-07$. 1945))

6. Id. at 107 (quoting Proclamation No. 2667, 10 Fed. Reg. 12,303 (Oct. 2,

7. Md. Monjour Hasan et al., Protracted Maritime Boundary Disputes and Maritime Laws, 2 J. INT'L MAR. SAFETY, ENVTL. AFF., \& SHIPPING 89, 89 (2018).

8. Richard J. McLaughlin \& Kateryna M. Wowk, Managing Areas Beyond National Jurisdiction in the Gulf of Mexico: Current and Developing International Legal Authority and Future Challenges, 9.2 SEA GRANT L. \& POL'Y J. 16, 20 (2018).

9. Id.

10. Id.

11. Id.

12. Henry Jones, Lines in the Ocean: Thinking with the Sea About Territory and International Law, 4 LONDON REV. INT'L L. 307, 334-35 (2016).

13. McLaughlin \& Wowk, supra note 9, at 21.

14. Id. 
on the continental shelf up to the coastal nations themselves. ${ }^{15}$ Many of these maritime borders are still contested with sovereigns unable to agree on many maritime boundaries for various legal, geographical, and geopolitical reasons. ${ }^{16}$ The United States and Mexico delineated the boundary of the Western half of the Gulf of Mexico ("GOM") in a 2000 treaty. ${ }^{17}$

Oil is a fugitive resource - it flows like water under the ground and lies pooled in rocks where Nature or Nature's God has deposited it irrespective of the boundaries mankind places on the surface of the earth. This can be especially problematic when drilling in deepwaterdeeper than 4,000 feet - or ultra-deepwater-deeper than 7,000 feet because of the high cost of drilling at such depths. ${ }^{18}$ The United States has generally applied the rule of capture to oil and gas production on land. The rule of capture states that regardless of whose land the oil reservoir may also be under, the first in time to drill and extract the oil owns the oil. ${ }^{19}$ Thus, on land, it is perfectly legal to extract oil that lies under someone else's property lines because the first in time to drill can legally siphon off the oil from the pool. ${ }^{20}$

Few other nations follow the rule of capture on land and have favored a legal process called "unitization" for offshore oil and gas reservoirs, which lay on both sides of a maritime boundary. ${ }^{21}$ Unitization is a standard method sovereigns use to efficiently share offshore resources. ${ }^{22}$ Unitization is the process of treating the reservoir as one unit, as if owned and operated by a single entity, to facilitate the most efficient means of extraction. ${ }^{23}$ The unitization of a transboundary reservoir usually requires a treaty between the nations

15. Id. at 35 .

16. For a list of main disputed areas, see Nicholas Newman, Maritime Boundary Disputes, ENIDAY https://www.eniday.com/en/human_en/maritime-boundarydisputes/ (last visited Feb. 16, 2019).

17. Guillermo J. Garcia Sanchez \& Richard J. McLaughlin, The 2012 Agreement on the Exploitation of Transboundary Hydrocarbon Resources in the Gulf of Mexico: Confirmation of the Rule or Emergence of a New Practice?, 37 Hous. J. INT'L L. 681, 740 (2015).

18. Jason Lavis, Shallow, mid to ultra deepwater definitions, DRILLERS (Apr. 6, 2018) https://drillers.com/shallow-mid-to-ultra-deepwater-definitions/.

19. Youri van Logchem, The Status of a Rule of Capture under International Law of the Sea with Regard to Offshore Oil and Gas Resource Related Activities, 26 Mich. ST. INT'L L. REV. 195, 201 (2018).

20. Id.

21. Id. at 217.

22. Id. at $218-219$.

23. SMith ET AL., supra note 4, at 167. 
the reservoir crosses so that the nations can govern the unitized area with one legal, tax, regulatory, and production scheme. ${ }^{24}$

Unitization is not uncommon in offshore oil and gas production because the square leasing blocks are imposed over the ocean. The United States and Mexico divide the GOM into square blocks for leasing to companies who explore for oil and gas reserves. ${ }^{25}$ However, subsoil reservoirs never conform to the blocks with geometric precision and can cross the blocks within one country's jurisdiction.

\section{HISTORICAL BACKGROUND OF THE 2012 TREATY}

\section{A. Mexico's Pre-Reform Hydrocarbon Regime}

In 1938, Mexico was the first country to nationalize the entire oil and gas sector. ${ }^{26}$ Before President Lázaro Cárdenas expropriated all foreign assets, the Mexican Constitution of 1917 had already reserved the ownership of subsoil hydrocarbons to the government. ${ }^{27}$ The International Oil Companies ("IOCs") issued an embargo against Mexican oil in the international market, forcing Mexico to sell its oil to Nazi Germany. ${ }^{28}$ While some United States officials urged dealing harshly with Mexico, President Roosevelt found it more important to maintain a good relationship with Mexico to prevent a possible alliance with the Axis Powers. ${ }^{29}$ Eventually, the Mexican Government compensated several American IOCs for the expropriations, but Mexico's state-owned oil company, Petróleos Mexicanos ("PEMEX"), retained its monopoly.

Eventually, PEMEX could not conduct the exploration needed to continue producing oil at sustainable rates. ${ }^{30}$ The Mexican

\footnotetext{
24. $I d$.

25. For leases on the US side of the gulf, see Bureau of Ocean Energy Management Gulf of Mexico Protraction Finder, http://www.arcgis.com/apps/View/index.html?appid=a20b30b37ae147a59afac8a8 $4 \mathrm{a} 2 \mathrm{~d} 4052$ \& extent $=-99.8775,22.3323,-78.7838,32.3452$. Note the green lease squares abutting the maritime border in the "Alaminos Canyon" leasing region. For the Mexican side, see https://portal.cnih.cnh.gob.mx/iicnih2/.

26. Office of the Historian, Mexican Expropriation of Foreign Oil, 1938, U.S. DEP'T OF STATE https:/history.state.gov/milestones/1937-1945/mexican-oil (last visited Feb. 2, 2019).

27. Richard H.K. Vietor \& Haviland Sheldahl-Thomason, Mexico's Energy Reform, HARV. BuS. SCH. CASE 717-027, January 2017. (Revised August 2017.) 1..

28. Office of the Historian, Mexican Expropriation of Foreign Oil, 1938, U.S. DEP'T OF ST. https:/history.state.gov/milestones/1937-1945/mexican-oil (last visited Feb. 2, 2019).

29. Id.

30. Sanchez \& McLaughlin, supra note 18, at 684 .
} 
Government utilized PEMEX's profits through heavy taxes and provided about one-third of the government's income by taxing its income at $69 \% .{ }^{31}$ By 2015, production in the once massive Cantarell field had fallen by $80 \%$, labor unions were extracting hefty profits, and PEMEX continued to maximize the volume of oil produced instead of the number of wells, leaving PEMEX short of cash to explore for new fields. $^{32}$

Meanwhile, IOCs developed the technology for extracting oil from ultra-deepwater reservoirs. As they expanded deeper into the Gulf of Mexico, the Mexican government grew concerned about a reservoir straddling both borders siphoning off oil from Mexican Territory, prompting national debate and pressure to create a treaty with the United States. ${ }^{33}$ Mexico's hydrocarbon law gave PEMEX exclusive rights to explore and produce oil, yet PEMEX lacked the resources and technology to exploit these deepwater reservoirs because their profits were funding government revenue instead of reinvesting in exploration and production. ${ }^{34}$ PEMEX's favored position posed a unique problem because they could neither legally nor financially undertake a joint venture in these ultra-deepwater fields. Additionally, PEMEX's oil production declined, compounding the problem and making the need for unconventional and deepwater exploration even more vital for Mexico's oil and gas industry to sustain itself. ${ }^{35}$

In 2012, United States and Mexican officials met to plan for deepwater exploration's expansion into the transboundary region of the GOM. The 2012 treaty they created was designed to work around the PEMEX monopoly while maintaining sovereignty over natural resources. $^{36}$ However, the United States failed to ratify it for nearly two years because it was caught up in political controversy. ${ }^{37}$ By 2014 , once it became clear that Mexico would pass energy reforms

31. Vietor \& Sheldahl-Thomason, supra note 28 , at 2.

32. Id. at 3 .

33. Sanchez \& McLaughlin, supra note 18 at 686, 689-690.

34. Constitución Política de los Estados Unidos Mexicanos, CP, art. 27, para. 1, Diario Oficial de la Federación [DOF] 1967; Javier Martínez-Romero, Ph.D., Innovation as an Imperative for the Mexican Oil Industry Post Energy Reform, JAMES A. BAKER III INST. FOR PUB. POL'Y, April 2017, at 1, 2.

35. Sanchez \& Mclaughlin, supra note 18 at 684.

36. Id. at 791 .

37. At the time there were tensions with IOC's because of some Dodd-Frank restrictions, see SENATE COMMITTEE PRINT, StAFF OF S. COMM. ON Foreign Relations, 112Th Cong., Oil, MeXico, And the Transboundary AGREEMENT 9, 15 (S. Print 2012); Sanchez \& Mclaughlin, supra note 17 at 751. 
liberalizing the oil monopoly by a complex constitutional amendment, the United States Senate ratified the treaty. ${ }^{38}$

The United States recognized that the trend in Mexico's hydrocarbon regime was towards reform, yet was skeptical of the stability of the transition. ${ }^{39}$ The United States was chiefly concerned with supporting anything that promoted IOC's willingness to invest in Mexican oil as the industry opened up. ${ }^{40}$ Economically, the United States recognized that Mexico supports United States energy security by being a reliable and friendly producer of oil in the region. ${ }^{41}$ Geopolitically, strengthening Mexico's hydrocarbon sector was important because unconventional resources in the United States and Canada as well as Mexico's untapped reserves were an important energy security issue. ${ }^{42}$ The United States Senate saw these new North American oil resources as a way to undermine the power of hostile authoritarian regimes reliant on hydrocarbons for funding, like Venezuela and Russia. ${ }^{43}$ The treaty incorporates these reasons but overall was meant to reduce legal uncertainty in the transboundary region to encourage IOC investment.

The 2012 treaty establishes a procedure for any exploration within three miles of the maritime boundary in the GOM. ${ }^{44}$ It requires licensees on either side to share geological information in this area annually and to provide written notice within sixty days of becoming aware of the "likely existence" of a transboundary reservoir. ${ }^{45}$ Once triggered, the parties have thirty days to initiate an investigation, and if the parties cannot determine whether a transboundary reservoir exists within sixty days, they must alert the Joint Commission. ${ }^{46}$ The Joint Commission is created by the United States and Mexico, consisting of one representative (and one alternate representative) from each party, chosen by the Executive Agency of each party. ${ }^{47}$ The Joint Commission is supposed to examine disputes, interpret the

38. Sanchez \& McLaughlin, supra note 18 , at 748.

39. STAFF OF S. COMM. ON FOREIGN RELATIONS, supra note 38, at 2-3.

40. Id. at 6 .

41. Id. at 11 .

42. Id. at $12-13$.

43. $I d$.

44. Agreement between the United States of America and the United Mexican States Concerning Transboundary Hydrocarbon Reservoirs in the Gulf of Mexico, U.S.-Mex., art. 4 §1, Feb. 20, 2012, T.I.A.S. 14-0718 (hereinafter "2012 Transboundary Treaty").

45. Id. at art 4. §2(a), (c).

46. $I d$. at art. $5 \S \S 1-2$.

47. $I d$. at art. $14 \S 2$. 
treaty, implement terms, and set rules of procedure. ${ }^{48}$ The Joint Commission may submit disputes, such as the existence of a transboundary reservoir, to an expert determination; initiate dispute resolution clause; or send the matter to non-binding mediation or arbitration. ${ }^{49}$ The Joint Commission must also establish the rules and procedure of arbitration. ${ }^{50}$

\section{B. Ratification and Energy Reform}

\section{Relevance of the Treaty Post-Reform}

Deepwater and ultra-deepwater oil production is incredibly costly. The United States Energy Information Agency estimated that one deepwater project by Chevron in the GOM took nine years to go from discovery to production and cost $\$ 91$ million per well, including a $\$ 258$ million pipeline. ${ }^{51}$ It takes an average of five drilling attempts before finding an economically productive hydrocarbon reserve. ${ }^{52}$ Oil companies want national offshore boundaries negotiated in a way that minimizes their investment risk because of the extremely high capital costs.

Mexico and the United States negotiated the 2012 treaty before Mexico's historic energy reforms when a joint venture was not legal. ${ }^{53}$ Since then, Mexico has granted licenses to foreign investors for deepwater exploration, creating unique complications for implementing the treaty. When the United States and Mexico ratified the treaty, IOCs in the United States side were already producing within the three-mile zone, meaning the oil reservoir could straddle the boundary. ${ }^{54}$ However, the United States exempted itself from retroactive enforcement of these wells in the treaty. ${ }^{55}$ Many of these operators were not grandfathered into the treaty, as the United States

48. Id. at art. $14 \S \S 4-5$.

49. $I d$. at art. $14 \S 8$.

50. Id. at art. 17.

51. U.S. Energy Information Administration, Trends in U.S. Oil and Natural Gas Upstream Costs 108-109, US DEP'T OF ENERGY (Mar. 2016), https://www.eia.gov/analysis/studies/drilling/pdf/upstream.pdf.
52. Will
Kenton, Exploratory
Well,
INVESTOPEDIA https://www.investopedia.com/terms/e/exploratory-well.asp (last updated June 25, 2019).

53. Sanchez \& McLaughlin, supra note 18 , at 748.

54. Id. at 740 .

55. Id. at $746-47$. 
did not force their licensees to modify their contracts to conform with the 2012 treaty. ${ }^{56}$

For example, the Perdido fold belt is a long geologic feature in the GOM consisting of a series of subterranean anticline formations found to contain oil on both sides of the maritime border. ${ }^{57}$ In the Perdido region, IOCs are already producing within a few miles of the maritime border, while Mexico has awarded an exploration license to a Chinese government owned company on their side of the GOM. ${ }^{58}$ It is possible that some of the wells on the United States side in Perdido straddle transboundary reserves, yet the licensees are under no treaty obligation to determine the boundaries. ${ }^{59}$ To date, neither side has attempted to determine whether a transboundary reservoir exists, which would trigger the treaty's implementation.

If the licensee that discovers a transboundary reservoir in their concession is a National Oil Company ("NOC") like Sinopec or the China National Offshore Oil Corporation ("CNOOC"), it would essentially invite a third government into the unitization negotiations. ${ }^{60}$ The government involved would learn a great deal about effectively negotiating transboundary contracts. Additionally, United States foreign policy has recently been more suspicious of Chinese investment in the United States' immediate sphere of influence. ${ }^{61}$

The 2013 reforms have allowed private companies to make joint production, profit sharing, licenses, and service contracts. ${ }^{62}$ However,

56. $I d$.

57. Javier H. Estrada, Reservoirs that Cross Country Lines Need Special Agreements, OFFSHORE MAG. (July 1, 2009), https:/www.offshoremag.com/articles/print/volume-69/issue-7/latin-america/reservoirs-that-cross.html.

58. Kristy Hays, UPDATE 1-Shell Starts Production at Perdido, REUTERS (Mar. 31, 2010, 5:32 PM), https://www.reuters.com/article/shell-perdido/update-1-shellstarts-production-at-perdido-idUSN3123683920100331; Shell Picks Up Nine Blocks in Mexico Offshore Lease Round, MAR. EXECUTIVE ( Jan. 31, 2018, 7:44 PM), https://www.maritime-executive.com/article/shell-picks-up-nine-blocks-inmexico-offshore-lease-round; Matt Zborowski, BHP, CNOOC, European Majors Among Winners for Mexican Deepwater Blocks, OIL \& GAS J. (Dec. 5, 2016), https://www.ogj.com/articles/2016/12/bhp-cnooc-european-majors-amongwinners-for-mexican-deepwater-blocks.html.

59. Sanchez \& McLaughlin, supra note 18, at 685.

60. See generally Jilles van den Beukel, Chinese National Oil Companies: Giants Built on Shaky Foundations, ENERGYPOST (Sept. 26, 2016), https://energypost.eu/chinese-national-oil-companies-giants-built-shakyfoundations/.

61. See Robert D. Kaplan, A New Cold War Has Begun, Foreign PoL'y (Jan. 7, 2019, 6:27 PM), https://foreignpolicy.com/2019/01/07/a-new-cold-war-has-begun/.

62. Sanchez \& McLaughlin, supra note 18, at 758. 
transboundary fields require at least 20\% participation with PEMEX, which further complicates negotiating the terms in a unitization agreement. ${ }^{63}$ In light of the Mexican energy reforms and foreign investment, it is unclear how relevant the treaty remains. If it is not relevant, it is still a binding treaty. In either case, states must clarify certain ambiguities in the treaty language for it to accomplish its goals effectively.

\section{Ambiguities and Their Political Impact}

The 2012 treaty requires the United States and Mexico to share all information obtained during exploration within three miles of the delimitation line. ${ }^{64}$ It requires a party aware of "the likely existence" of a transboundary reservoir to provide written notice and share seismic data. ${ }^{65}$ International law generally requires a standard of good faith to interpret treaty language which is necessarily vague, such as "likely existence." 66 The interpretation could be complicated when the parties of the treaty are two sovereign nations and the licensees exploring for oil reservoirs are IOCs and foreign state-owned companies.

The capital risks and the high cost of obtaining reliable seismic data provide some incentive to interpret the data in a way that shows transboundary reservoirs do not exist. On the other hand, for Mexico, which lacks infrastructure, investment, and capital, there is an incentive to interpret seismic date liberally to provide for a transboundary reservoir. Some voices in Mexican politics believe that oil companies on the United States side of the maritime border are extracting from transboundary reservoirs, but this is not confirmed. ${ }^{67}$

No language specifies when economic efficiency should yield to environmental concerns or State interests. ${ }^{68}$ The United States Senate, while urging the treaty's ratification, tacitly acknowledged that the "plain language" failed to improve environmental safety standards and could even lower existing standards. ${ }^{69}$ The Senate committee was concerned that this would result in lower standards by delegating

63. Id. at 759 .

64. 2012 Transboundary Treaty, supra note 45 , at art. $4, \S 1$.

65. Id. at art. 4, § 2(a)-(b).

66. Vienna Convention on the Law of Treaties art. 31(1), May 23, 1969, 1155

U.N.T.S. 336; 2012 Transboundary Treaty, supra note 45, at art. 4, § 2.

67. Sanchez \& Mclaughlin, supra note 18 at 686.

68. Id. at 753 .

69. See Staff of S. Comm. On Foreign Relations, supra note 38, at 9-10. 
authority to the appropriate executive appointee to define the standards. ${ }^{70}$ Environmental safety standards became increasingly important after the high profile oil spill by British Petroleum in $2010 .^{71}$

The ambiguities in the treaty are problematic because Mexico considers these resources property of the State for the benefit of the nation, while the United States sees oil production as a national security issue, necessitating that private companies exploit the resources efficiently. ${ }^{72}$ These interests are not directly in conflict, but different situations could lead the parties to desire different outcomes. Mexico's nationalistic approach makes them less willing to see profits flow out of Mexico, while the United States's view of oil as a national security issue desires resource development that stabilizes the Mexican nation and economy concerning their place in the global marketplace.

In the United States view, foreign investment in Mexico's energy sector contributes to political stability in Mexico. Political instability leading to upheaval or investment by hostile foreign powers are important concerns. Chinese NOC investment in Mexican offshore oil potentially allows Chinese geopolitical influence in the Gulf of Mexico and may lead the United States to be less charitable in negotiating a unitization contract. ${ }^{73}$ The United States is pressuring nations in Central America to avoid business ties with Chinese stateowned corporations. ${ }^{74}$ The United States's economic tensions with Chinese investors could easily lead to a dispute about the terms of unitization while implementing the treaty.

70. Specifically, the Secretary of the Interior, Id. at 10.

71. Terese Collins, The Gulf Oil Spill, SMITHSONIAN (April 2018), https://ocean.si.edu/conservation/pollution/gulf-oil-spill.

72. Sanchez \& McLaughlin, supra note 18, at 754.

73. Compare to Chinese investment in Venezuela and the US response, Antonio C. Hsiang, China and the Venezuela Crisis, Diplomat (July 24, 2017), https://thediplomat.com/2017/07/china-and-the-venezuela-crisis/. For a more detailed look at Chinese investment in Venezuela in the context of Chinese geopolitical ambitions, with a recommendation for a hard stance from the US, see Moises Rendon, When Investment Hurts: Chinese Influence in Venezuela, CTR. FOR STRATEGIC \& INT'L STUD. (April 3, 2018), https://www.csis.org/analysis/wheninvestment-hurts-chinese-influence-venezuela

74. Edward Wong, Mike Pompeo Warns Panama Against Doing Business With China, N.Y. TIMES (Oct. 19 2018), https:/www.nytimes.com/2018/10/19/world/americas/mike-pompeo-panamachina.html?module=inline. 


\section{Potential Disputes \& Resolution}

\section{A. The Rule of Capture and International Law}

Mexico's concern is that if a United States licensee invokes the rule of capture in a transboundary reservoir, it will effectively steal resources the government owns, and they will lose profits and rents they deserve. International law generally rejects the rule of capture in favor of good faith requirements of dealing between sovereigns. ${ }^{75}$ Additionally, most governments agree that applying the rule of capture is not in their best interest, as it leads to competitive drilling, inaccessible resources, and inefficiency. ${ }^{76}$ Avoiding competitive drilling is a significant state goal when negotiating transboundary agreements because both sides typically lose by not extracting the oil as efficiently. ${ }^{77}$ Oil and gas reserves are fugitive resources that will travel from their location to the well or place of extraction. ${ }^{78}$ Several nations have reached agreements for joint development or unitization that reject the rule of capture and this possibly establishes a rejection of the rule of capture according to customary international law. ${ }^{79}$

In addition to customary international law, UNCLOS articles 74(3), 84(3), and two United Nations Assembly Resolutions also support the position that cooperative development of offshore transboundary reserves is the international standard. ${ }^{80}$ Supporting the theory that international law bars competitive drilling, the International Court of Justice ("ICJ") decided that states are obliged to behave as good neighbors (sic utere tuo, ut alienum non leaedas) as a rule of customary international law. ${ }^{81}$ However, these laws are not definitive, and a dispute over transboundary reserves is what Saddam Hussein alleged justified his invasion of Kuwait. ${ }^{82}$ Applied to oil and gas reserves, the rule of capture would cause a loss of these resources to one nation, and such an action by one state against another state's claims and sovereign rights is likely to cause an international confrontation. ${ }^{83}$

75. van Logchem, supra note 20, at 203.

76. $I d$.

77. Sanchez \& McLaughlin, supra note 18.

78. van Logchem, supra note 20, at 198.

79. SMITH ET AL., supra note 5, at 166.

80. Id. at $166-167$.

81. See North Sea Continental Shelf, (Ger./Den; Ger./Neth.), Judgment, 1969

I.C.J Rep. 3, 19 (Feb. 20) cited in van Logchem, supra note 20.

82. SMITH ET AL., supra note 5, at 167.

83. van Logchem, supra note 20, at 219-220. 
However, even before the treaty, some scholars pointed out the inevitability of an operator applying the rule of capture. Professor Grunstein highlighted that if a licensee who has invested 500 million dollars in exploration discovers a transboundary reservoir, they are not going to stop production while the United States and Mexico negotiate the unitization details according to the treaty. ${ }^{84}$ Additionally, some states have taken actions that seem to invoke the rule of capture over subsoil resources in a disputed maritime border. Ghana caused an international incident when Ghana and Cote D'Ivoire were waiting for a ruling over a disputed maritime area, and Ghana began moving infrastructure as if they were still planning on producing the resources. ${ }^{85}$ Arguably, exploration activity, like seismic surveys and exploratory wells in a disputed area, can violate the international law principle against aggravating a dispute. ${ }^{86}$ Commencing drilling in a transboundary region comes with serious consequences and is based on dubious legal grounds.

PEMEX is supposed to participate in any offshore transboundary reservoirs, but it could take years before PEMEX has the resources to contribute more than cash to deepwater hydrocarbon production. ${ }^{87}$ IOCs will be less likely to explore for oil in the area if there is a chance they have to delay production so that the United States and Mexico can figure out how to incorporate PEMEX into their unitization agreement. Several scholars proposed to solve this problem by putting the proportion of funds due to Mexico into an escrow fund until the treaty details have been sorted out. ${ }^{88}$ University of Dundee Professor Peter Cameron first advocated this approach as a solution that would allow drilling to continue promptly without invoking the rule of capture. $^{89}$

This approach could lead to drilling before the licensees find the best spot to drill, and customary international law on this topic remains scarce. ${ }^{90}$ However, it resolves many problems by preventing a halt of production while the treaty details are sorted out. Escrow would be a

84. Miriam Grunstein, Unitized we Stand, Divided we Fall: A Mexican Response to Karla Urdaneta's Analysis of Transboundary Petroleum Reservoirs in the Deep Waters of the Gulf of Mexico, 33 Hous. J. INT'L L. 345, 364 (2011).

85. van Logchem, supra note 20, at 204.

86. Id. at 205-206.

87. Grunstein, supra note 85 , at 358 .

88. This approach is advocated by Professors Sanchez, McLaughlin, and Cameron. Sanchez \& McLaughlin, supra note 18 at 708.

89. Id.

90. Id. at 709 . 
fairer option for the governments on both sides, while the licensees will likely object because they potentially lose opportunity costs when oil profits are locked in escrow instead of in their cash flow while various parties debate unitization. Once again, the problem comes from the parties' misaligned interests. The United States and Mexico want to ensure they are not losing out on natural resource revenue over time, while an IOC that has invested 500 million dollars over the better part of a decade wants to start seeing a return on their investment. As the interests of United States and Mexico are greater than IOC revenue, IOC cash flows will probably need to temporarily yield to soveriegn perogatives by sending profits into escrow in order to preserve peace and allow production to continue.

The escrow solution, while applying international law principles of equity, good faith, and fair dealing, is complicated in several situations. Because of the complexities of determining whether a transboundary field exists, wells may already be producing from transboundary fields. ${ }^{91}$ The United States awards blocks to oil companies for exploration in the GOM roughly nine square miles in size. ${ }^{92}$ The Neptune Field, a deepwater field 120 miles from Louisiana, spans five of these nine square mile blocks. ${ }^{93}$ Thus, it is entirely possible that there are unknown deepwater and ultra-deepwater reservoirs that lessees may discover outside the three-mile reporting zone required by the treaty, which could still cross the boundary. ${ }^{94}$ If a licensee discovers a transboundary reservoir, and the American side has been producing for several years already, the escrow option will probably be reasonable to apply, but the treaty does not explicitly provide for the contingency, making the transaction ripe for conflict.

\section{B. Points of Contention}

Of course, no parties plan on an unresolvable dispute while negotiating unitization. The 2012 treaty leaves dispute resolution fairly vague, establishing expert determination, non-binding mediation, and arbitration in different situations. ${ }^{95}$ The Joint Commission is supposed to establish the procedure and mechanism

91. Id. at 685 .

92. Glossary, Bureau OF SAFETY \& ENVTl. ENFORCEMENT, https://www.bsee.gov/newsroom/library/glossary (last visited Feb. 2, 2019).

93. Neptune Field, Gulf of Mexico, OFFSHORE TECH. https://www.offshoretechnology.com/projects/neptune-field/ (last visited Feb. 2, 2019).

94. 2012 Transboundary Treaty, supra note 45 , at art. 4 \$2(f).

95. 2012 Transboundary Treaty, supra note 45 , at art. 15. 
for arbitration. ${ }^{96}$ The Joint Commission consists of two members (and two alternates) appointed by each nation's executive agency. ${ }^{97}$ Two political appointees are unlikely able to create a satisfactory arbitration regime for a high-stakes international business deal like a unitization agreement. Transboundary unitization contracts are incredibly complex, multiplying the opportunity for disputes to arise.

A significant point of contention could conceivably be designating the unit operator. The 2012 treaty states that the Executive Agencies will pick the unit operator "by agreement between the licensees." 98 Designating the unit operator could become extremely complicated. For example, suppose a Chinese licensee on the Mexican side discovers they have been unknowingly producing from a transboundary reservoir for several years and two different IOCs were producing from the same reservoir on the United States side. In a joint operating agreement, the operator is usually the party with the greatest interest in the venture. ${ }^{99}$ Mexico requires offshore licensees to accept PEMEX's participation in an agreement by at least $20 \%,{ }^{100}$ adding fourth potential operator. Mexico may want their Chinese licensee to be operator because of their view of oil as a national asset, even though the IOCs clearly had a greater interest. The Joint Commission would send proportionality and other issues to expert determination while negotiating the unitization agreement. ${ }^{101}$ The Joint Commission could handle these contingencies if it could be strengthened to provide expertise and transparency to ensure adaptability.

\section{FUTURE CONCERNS}

\section{A. Strengthening the Joint Commission}

The treaty ultimately needs amendment or revision now that Mexico has opened to private investment. The parties could either completely terminate the treaty or amend it. Termination merely

96. Id. at art. 17 .

97. $I d$. at art. $14 \S 2$.

98. Id. at art $10 \S 1$.

99. SMITH ET AL., supra note 5, at $542 .$.

100. Analysis of Mexico's New Hydrocarbons Legal Regime, MAYER BROWN 6 (Aug. 14, 2014), https://www.mayerbrown.com/files/Publication/69fe7acd-ca5b4d1 c-a172-31678b13ec06/Presentation/PublicationAttachment/75b0fe83-d4a24523-b8e2-3f7ae78102a7/UPDATE-Analysis-of-Mexicos-New-HydrocarbonsLegal-Regime.pdf.

101. 2012 Transboundary Treaty, supra note 45 , at art. $14 \S \S 6-8$. 
requires 180 days' notice by either party. ${ }^{102}$ It can be amended at any time by mutual written agreement. ${ }^{103}$ In either case, the cumbersome legislative process of the United States Senate providing its advice and consent could take even longer to ratify the new treaty or amendments. ${ }^{104}$ As of 2018, seven treaty amendments were pending in the United States Senate, the earliest introduced in $1983 .{ }^{105}$ The oil companies who bear the financial risk want the procedure as clear as possible to ensure they can see a return on their investment. The best option is probably to utilize the broad, vague language in the treaty by strengthening the Joint Commission into a body competent to establish an efficient procedure and make good decisions.

To do this, the Joint Commission should establish one or more subsidiary committees of experts to create the policy and procedure, whose decisions will only become binding once ratified by the Joint Commission. This way the Joint Commission can have the expertise of more impartial industry experts rather than mere political appointees but still maintain state sovereignty because the two Joint Commission members would retain ultimate veto power.

From a geopolitical standpoint, the United States wants Mexico's offshore resources developed, mainly by IOC capital and expertise, more than it cares about extracting rents in the transboundary region. ${ }^{106}$ Because the Mexican Government gets $20 \%$ of its revenue from oil production, it produces stability in the region to the benefit of the United States the more Mexico's oil reserves are efficiently exploited. ${ }^{107}$ A productive Mexican oil and gas sector will contribute to political and social stability because the government will be wellfunded and can maintain its extensive entitlement programs without angering the powerful labor unions. Additionally, the energy sectors of both countries are highly intertwined. In 2017, although the United States imported more crude oil from Mexico than it exported to Mexico, United States oil exports to Mexico accounted for over 50\% of Mexico's gasoline use. ${ }^{108}$ It is thus in the interests of both countries,

102. Id. at art 23 .

103. Id. at art 21 .

104. U.S. CONST., art. II, § II, cl. II.

105. Treaties Pending in the Senate (updated as of July 17, 2019), U.S. DEPT. OF STATE https://www.state.gov/s/l/treaty/pending/ (last visited Sept. 22, 2019).

106. StAFF OF S. COMM. ON FOREIGN RELATIONS, supra note 38, at 2.

107. Amy Stillman, Mexico's Struggling State Oil Company Awaits New President's Risky Fix, BloOMBERG (Aug. 14, 2018, 6:01 AM), https://www.bloomberg.com/news/articles/2018-08-14/a-cash-cow-on-its-last-legsmexican-oil-awaits-amlo-s-risky-fix.

108. U.S. Embassies, Mexico - Oil and Gas, InT'L Trade Ass'n, DePT. OF CoM. 
one as a net importer and the other as a net exporter, to resolve disputes in oil production promptly. ${ }^{109}$ The treaty is not especially helpful in this case because specific procedure and terms have been left up to the future Joint Commission to decide. ${ }^{110}$

Because difficulties can easily arise, both states are put in a position to leverage an imbalance in the unitization agreement or production terms near the three-mile area in the event of a dispute. Once an oil or gas reserve is found, it takes about ten years before production begins. ${ }^{111}$ Because standard practice is on such a long timeframe, IOCs are hemorrhaging money during exploration and drilling and want legal issues like unitization resolved with certain promptness. Additionally, the transboundary region has the potential to quickly become very politicized, as it has been in Mexico. ${ }^{112}$ These critical political and financial concerns necessitate effective treaty implementation so that unitization occurs smoothly and equitably.

However, the treaty's vague terms only put an obligation on both governments to attempt to negotiate, while leaving many of the decisions to the Joint Commission. If negotiations for unitization fail, the treaty implicitly allows both sides to continue production by only stipulating non-binding mediation. ${ }^{113}$ In contrast to standard international practice, the arbitration clause says nothing about consent to arbitrate or the finality of the decision. ${ }^{114}$ Standard international practice as used in the Iceland-Norway treaty and the Timor Gap treaty is to explicitly state that disputes "shall be submitted" to arbitration; that any award "shall be final and binding;" and how arbitrators are chosen. ${ }^{115}$

Because the parties have not agreed that the arbitration will be binding, either party could refuse to comply with an arbitrator's decision. Curiously, if the Joint Commission cannot agree to mediation and expert determination, then the arbitration will be conducted according to rules established by the Joint Commission. ${ }^{116}$ Thus, the parties already in disagreement will have to establish the rules for resolving their disagreement while frustrated by the

(Oct. 12, 2018), https://www.export.gov/article?id=Mexico-Upstream-Oil-and-Gas. 109. Id.

110. 2012 Transboundary Treaty, supra note 45 , at art. 17.

111. van Logchem, supra note 20, at 240.

112. STAFF OF S. COMM. ON FOREIGN RELATIONS, supra note 38, at 9.

113. 2012 Transboundary Treaty, supra note 45 , at art. $15 \S 3$.

114. Sanchez \& McLaughlin, supra note 18, at 762.

115. Id. at 762-63.

116. 2012 Transboundary Treaty, supra note 45 , at art. 17. 
disagreement. This dispute resolution clause could lead to competitive drilling by explicitly allowing a licensee to produce oil in the event negotiations fail. ${ }^{117}$ As discussed, competitive drilling in the face of a dispute would likely conflict with international law. ${ }^{118}$

Arbitration could also be subject to legal challenge in both countries and fail even if the treaty followed standard practice for international transboundary treaties by specifying binding arbitration. ${ }^{119}$ In 2008, the United States Supreme Court decided in Medellin v. Texas that international treaties may be binding law for the federal government but not enforceable in United States courts if Congress did not pass "implementing legislation" to make ICJ decisions binding domestic law. ${ }^{120}$ In Medellin, the United States lost a case at the ICJ against Mexico for not informing Mexican nationals sentenced to death of their right to contact a consulate under the Vienna treaty. ${ }^{121}$ The Court declared Article 36 of the Vienna treaty not self-executing and said for decisions from international arbitrators or tribunals to be effective, Congress had to pass implementing legislation that explicitly stated that decisions constitute binding domestic law. ${ }^{122}$ In light of constant congressional gridlock, this is highly unlikely to happen.

Additionally, when the 2012 treaty was ratified, Mexico was exempted from North American Free Trade Act ("NAFTA") chapter 11 , dealing with energy and international investment arbitration as the legal regime barred foreign investment at the time. ${ }^{123}$ After Mexico's energy reforms it was unclear whether Mexico implicitly consented to oil and gas disputes to NAFTA chapter 11 and Investor-State Dispute Settlement ("ISDS"). ${ }^{124}$ NAFTA's replacement treaty ${ }^{125}$ removes most ISDS mechanisms, with the exception of certain oil and gas disputes between Mexico and the United States. ${ }^{126}$ Oil companies

117. Sanchez \& McLaughlin, supra note 18 , at 786 .

118. Id. at 701-02.

119. Id. at 765 .

120. 552 U.S. 491, 504-05 (2008).

121. Id. at 497-98.

122. $I d$. at $504-05$.

123. Bradley J. Condon, Mexican Energy Reform and NAFTA Chapter 11: Articles 20 and 21 of the Hydrocarbons Law and Access to Investment Arbitration, 9 J. WORLD ENERGY L. \& BUS 203, 204 (2016).

124. See id. (arguing that Mexico is subject to NAFTA chapter 11 after the energy reforms).

125. See infra SECTION IV.B.

126. Heather Long, The USMCA is finally done. Here's what is in it., WASH. POST (Dec. 10, 2019, 4:13 PM), https://www.washingtonpost.com/business/2019/12/10/usmca-is-finally-done-dealafter-democrats-sign-off-heres-what-is-it/. 
lobbied for ISDS due to fear the Mexican Government would attempt to nationalize the oil industry. ${ }^{127}$ ISDS for Oil and Gas against Mexico generally does not allow claims regarding minimum standard of treatment, indirect expropriation, or acquisition claims, and requires exhaustion of local remedies, making a dispute unlikely to reach the arbitrators. ${ }^{128}$ In reality, the new provisions for Oil and Gas dispute resolutions reflect the broader trend of international law moving away from international bodies in favor of States acting in more direct national interest. ${ }^{129}$ Thus, even if the language in the treaty conformed to standard international practice, a dispute against the United States is subject to challenge under Medellin and faces an uncertain ISDS regime against Mexico. Because the dispute resolution mechanism is so uncertain, it is necessary to ensure the Joint Commission can make decisions that neither side is likely to reject.

The Joint Commission's structure in the treaty is not especially robust. ${ }^{130}$ The Commission is made up of a representative from each party but depends on the respective executive authorities for funding. ${ }^{131}$ As the treaty grants the Joint Commission broad authority to interpret and implement the treaty as they unitize a transboundary reservoir, it needs more impartiality to reach agreements. ${ }^{132}$

One option would be to strengthen the Joint Commission by structuring it more like the International Boundary Water Commission ("IBWC"). ${ }^{133}$ The Joint Commission's structure is in stark contrast to the IBWC, which operates as a bilateral international organization with clear qualifications for its members. The IBWC is divided into Executive, Operations, Engineering, and Administration departments, while operating as independent and impartially as possible. ${ }^{134}$ The IBWC began in 1889 to oversee transboundary groundwater resources between the United States and Mexico according to rules agreed on in the 1884 convention. ${ }^{135}$ As an entity dealing with treaty

127. Id.

128. Sergio Puig, Can International Trade Law Recover? The United StatesMexico-Canada Agreement: A Glimpse Into the Geoeconomic World Order, 113 AJIL UNBOUND 56, 57 (2019).

129. Id.

130. 2012 Transboundary Treaty, supra note 45 , at art. 14.

131. Sanchez \& McLaughlin, supra note 18 , at 761.

132. Id. at 761-62;2012 Transboundary Treaty, supra note 45, at art. $14 \S 5$.

133. See generally U.S. IBWC Organizational Structure, INT'L BOUNDARY \& WATER COMM'N, https://www.ibwc.gov/organization/organization.html (last visited March 2, 2019).

134. Id.; Sanchez \& McLaughlin, supra note 18, at 761.

135. See Convention between the United States and Mexico Water Boundary, 
implementation over fugitive transboundary resources between the United States and Mexico for over a century, though it deals in a different field of law, some of the institutional knowledge gained from the IBWC could empower the Joint Commission in its mission.

The Joint Commission can be strengthened by the two executive representatives making appointments to subsidiary committees like the IBWC departments, which would craft the necessary procedure and policy. Generally, the Joint Commission could give deference to committee decisions because of their expertise but the Joint Commission would retain veto power via their power granted in the treaty. State sovereignty would be preserved because the Joint Commission would ultimately ratify a committee decision for it to become binding, but the committees would be better at creating the policies than the Joint Commission.

Some of the knowledge the IBWC has of dealing with a fugitive resource across borders is not relevant because the law treats water differently than minerals like hydrocarbons. ${ }^{136}$ Thus, rather than merely borrowing members from the IBWC, respective executive agencies need to pick some committee members with expertise in the international oil and gas industry. To balance the industry concerns, members should also be impartial, as both governments want the resources shared equitably. The IBWC has a history of equitably and successfully negotiating the sharing of fugitive resources between Mexico and the United States. ${ }^{137}$

Though the IWBC lacks hydrocarbon industry expertise, its analogous expertise merits its involvement. Because the treaty leaves so much up to the Joint Commission to decide, the Joint Commission would be more effective and independent if the subsidiary committees are drawn from entities like the IWBC, arbitrators, and international law experts. ${ }^{138}$ According to the treaty, no committee decision could become law until the Joint Commission approves it. This delegation of authority makes their decisions less politicized, while the expertise

Extending the Duration of the Convention of March 1, 1889, U.S.-Mex., Mar. 1, 1889, T.S. No. 241, https://www.ibwc.gov/Files/TREATY_OF_1889.pdf.

136. For a discussion of the application of international groundwater law to international disputes and international organizations, see Gabriel Eckstein, Application of International Water Law to Transboundary Groundwater Resources, and the Slovak-Hungarian Dispute over Gabcikovo-Nagymaros, 19 SUFFOLK TRANSNAT'L L. REV. 67 (1995).

137. See Stephen P. Mumme, Scarcity and Power in US-Mexico Transboundary Water Governance: Has the Architecture Changed since NAFTA?, 13 GLOBALIZATIONS 702 (2016).

138. Id. 
involved makes it more likely good and equitable decisions are reached, making it less likely parties to the unitization agreement opt for arbitration at all.

Ideally, such a unitization agreement should be similar to a production-sharing agreement. ${ }^{139}$ However, production-sharing contracts work because the parties negotiate the terms before production begins. Though production-sharing agreements typically have set times to re-adjust the terms as more accurate seismic data is uncovered, the dynamics do not apply quite the same way in unitization. For an IOC that has spent ten years and several hundred million dollars establishing an ultra-deepwater well, the political risk of drilling close to maritime borders with a disputed legal framework may deter investment. If IOCs thought that exploration too close to the border could potentially result in an unfair production sharing agreement being forced on them after beginning production, it could potentially halt exploration in the area because the risk is too great.

Ultimately, it is in the interest of both nations to formalize cooperation mechanisms so that common safety, infrastructure, and environmental standards can develop as licensees discover more offshore oil fields in the GOM. ${ }^{140}$ This goal is related to the United States' greater geopolitical concerns of keeping Mexico's energy reform alive by bringing stability so that IOCs can invest in the country, and PEMEX can gain expertise and technology by working with them. Though Mexican stability is a key concern, the United States also sees domestic offshore oil production as a benefit for energy security and thus wants to encourage investment in the region. ${ }^{141}$ In recent years, developed nations have opted to move away from international bodies in legal adjudication in favor of national discretion. ${ }^{142}$ A state that submits itself to an international body cedes some amount of sovereignty, and economic powerhouses like the United States are inevitably less likely to concede to international bodies. Strengthening the Joint Commission by creating specialized committees to create unitization policies and fill in the gaps for the Joint Commission to approve provides the best chance that the treaty

139. StafF OF S. COMM. On Foreign Relations, supra note 38, at 10.

140. Guillermo J. Garcia Sanchez, Mexico's Energy Reform and the 2012 USMexico Transboundary Agreement. An opportunity for Efficient, Effective and Safe Exploitation of the Gulf of Mexico, 9 SEA GRANT L. \& POLICY J. 1, 4 (2018).

141. StafF OF S. COMM. On Foreign RELATIONS, supra note 38, at 10.

142. Puig, supra note 129. 
succeeds by minimizing the risk of dispute resolution derailing the negotiations.

\section{B. AMLO, USMCA, \& Geopolitics}

The Mexican administration, which pushed through the liberalizing constitutional reforms in the energy sector, hoped that incorporating the reforms into the Trans-Pacific Partnership ("TPP") would make Mexico's energy sector permanently open to foreign investment. ${ }^{143}$ The election of Donald Trump meant that the United States would not join the TPP, which weakened Mexico's plan, but another election has jeopardized the reforms. ${ }^{144}$ The 2018 election of Andrés Manuel López Obrador (“AMLO") will likely complicate implementing the 2012 treaty and could potentially turn a dispute in the boundary area into international contention. AMLO, a staunch opponent of the 2014 reforms who the media has dubbed as the "Mexican, left-wing Donald Trump," has vowed to undo the privatization of Mexico's hydrocarbon industry. ${ }^{145}$ AMLO is no friend to industry investors and in 1992, even led environmental protests against PEMEX. ${ }^{146}$ Because of the ambiguity of the treaty, and the politicization of transboundary reservoirs in Mexican politics, AMLO could conceivably claim the United States has violated the terms of the treaty, causing an international incident. ${ }^{147}$

The AMLO administration quickly showed a willingness to adhere to radical campaign promises by halting construction of a partiallyconstructed $\$ 13$ billion airport. ${ }^{148}$ In a shock to hydrocarbon investors,

143. Camilo Soto Crespo, A Mexican Outlook on NAFTA, TPP and their Renegotiation: Investment Arbitration's Transparency and International Supervision at Peril?, 40 Hous. J. INT'L L. 938, 983. (2018).

144. Peter Baker, Trump Abandons Trans-Pacific Partnership, Obama's Signature Trade Deal, N.Y. TIMES (Jan. 23, 2017), https://www.nytimes.com/2017/01/23/us/politics/tpp-trump-tradenafta.html?module $=$ inline.

145. Nacha Cattan, et. al, AMLO Wins Big and All Eyes Turn to Battle for Mexico's Congress, BloOMBERG (July 1, 2018, 6:00 AM), https://www.bloomberg.com/news/articles/2018-07-01/mexico-heads-to-pollswith-leftist-on-brink-of-historic-victory.

146. Armando Guzman \& Rosalia Vegara, AMLO: Vocacion de Resistencia, PROCESO (Mar. 30, 2012), https://www.proceso.com.mx/302704/amlo-vocacionde-resistencia.

147. StafF of S. COMM. On Foreign Relations, supra note 38, at 12.

148. Aileen Cho, \$13B Mexico City Airport Project Apparently Axed by President-Elect, ENGINEERING NEWs REC. (Nov. 7, 2018), https://www.enr.com/articles/45812-13b-mexico-city-airport-project-apparentlyaxed-by-president-elect. 
before his inauguration, his administration announced they would review all exploration and production contracts awarded to private companies after the energy reforms "for signs of corruption." 149 About two weeks later, AMLO called the executives of companies awarded contracts and informed them Mexico would honor their contracts if the oil companies could "meet existing terms" and indicated his administration would address regulatory bottlenecks but would still review the contracts. ${ }^{150}$ A month later, AMLO announced he would suspend future planned bidding rounds until the 107 awarded contracts started producing oil. ${ }^{151}$

AMLO then somewhat ominously told investors, "we expect results" and unveiled an ambitious goal of increasing Mexico's oil output and investing $\$ 3.9$ billion in PEMEX's exploration and production. ${ }^{152} \mathrm{He}$ subsequently offered a three-year "truce" to companies who previously won bidding rounds. ${ }^{153}$ This was in his first few months in office, and the administration is also fulfilling AMLO's vow to fight fuel theft by shutting down key pipelines and reducing United States oil imports. ${ }^{154}$ These early events show that AMLO may not follow through with his rhetoric but is willing to make decisions that are not economically viable because of his commitment to Mexico's sovereignty over hydrocarbon resources, and what he feels

149. Mexico's AMLO Starts Oil Contract Reviews to Tackle Corruption, TELESUR (Sept. 18, 2018), https://www.telesurenglish.net/news/Mexicos-AMLO-Starts-OilContract-Reviews-to-Tackle-Corruption-20180918-0021.html.

150. Adriana Barrera, Mexico's next president will honor existing oil contracts $\begin{array}{lllll}\text { official, REUTERS (Sept. 27, 2018, } & 5: 35 & \text { PM), }\end{array}$ https://www.reuters.com/article/mexico-oil/mexicos-next-president-will-honorexisting-oil-contracts-official-idUSL2N1WD1TQ.

151. Andrew Baker, AMLO to Suspend Mexico Bid Rounds Until Current Projects Start Producing, NATURAL GAS InTElligence (Oct. 18, 2018), https://www.naturalgasintel.com/articles/116170-amlo-to-suspend-mexico-bidrounds-until-current-projects-start-producing.

152. Andrew Baker, Mexico E\&P Auctions to be Suspended Until Current Projects Start Producing, President-Elect Says, NATURAL GAS InTELligence (Oct. 23, 2018), https:/www.naturalgasintel.com/articles/116214-mexico-ep-auctionsto-be-suspended-until-current-projects-start-producing-president-elect-says;

Bloomberg, AMLO targets \$3.9 billion in new Mexico oil investment, JWN ENERGY (Sept. 11, 2018, 7:08 AM), https:/www.jwnenergy.com/article/2018/9/amlotargets-39-billion-new-mexico-oil-investment/.

153. Andrew Baker, AMLO Offers Three-Year 'Truce' to Oil, Gas Bid Round Winners, NATURAL GAS INTELLIGENCE (Dec. 7, 2018), https://www.naturalgasintel.com/articles/116712-amlo-offers-three-year-truce-tooil-gas-bid-round-winners.

154. Robbie Whelan \& Rebecca Elliott, Mexico Reduces U.S. Gasoline Imports, WALL St. J. (Jan. 11, 2019 6:30 PM), https://www.wsj.com/articles/mexicoreduces-u-s-gasoline-imports-11547249440. 
is best for his people. AMLO could potentially complicate a transboundary negotiation by public rhetoric alone.

Before his election, some scholars hoped that the NAFTA renegotiations would help president Peña Nieto's energy reforms apply more permanently. ${ }^{155}$ The Trump Administration's renegotiation of NAFTA (United States, Mexico, and Canada Agreement "USMCA") complicates the energy relations between Mexico and the United States. When the United States and Mexico drafted the 2012 treaty, Mexico had reservations from NAFTA's dispute resolution chapter regarding oil and gas to preserve the PEMEX monopoly. ${ }^{156}$ USMCA was signed into law by President Trump on January 29, 2020. ${ }^{157}$ Under USMCA, Mexico's oil and gas sector is subject to ISDS for disputes against the United States in limited situations, excluding indirect expropriation, establishment and acquisition claims, and only after local remedies are exhausted. ${ }^{158}$

The 2012 treaty does not eliminate either party's rights in other treaties. ${ }^{159}$ Thus, USMCA's dispute resolution provisions apply to a confirmed transboundary reservoir in the treaty region. ${ }^{60}$ The governmental actions over a transboundary reservoir within the scope of USMCA's dispute resolutions are limited, to the chagrin of investors. ${ }^{161}$ Contracts Mexico awards to foreign investors can only be submitted to ISDS for direct expropriation, violation of national treatment, and violation of the Most Favored Nation provision, and only after local remedies are exhausted. ${ }^{162}$ Additionally, national treatment claims regarding establishment or acquisition of an investment are expressly excluded. ${ }^{163}$ These sectorial limits to ISDS against Mexico were criticized by experts who were otherwise pleased

155. Crespo, supra note 143, at 977-78.

156. Condon, supra note 124, at 206.

157. President Donald J. Trump's United States-Mexico-Canada Agreement Delivers a Historic Win for American Workers, WHITE House (Jan. 29, 2020), https://www.whitehouse.gov/briefings-statements/president-donald-j-trumpsunited-states-mexico-canada-agreement-delivers-historic-win-american-workers/.

158. See United States-Mexico-Canada Agreement, Can.-Mex.-U.S., Ch. 14 Annex E, Ch. 31, Nov. 30, 2018, https://ustr.gov/trade-agreements/free-tradeagreements/united-states-mexico-canada-agreement/agreement-between; Puig, supra note 129.

159. 2012 Transboundary Treaty, supra note 45 , at art 25.

160. Id.; see also Condon, supra note 124, at 206 (discussing the likely application of NAFTA chapter 11 after the 2014 reforms).

161. Zara Shafruddin, Investor-State Dispute Settlement Between Developed Countries: Why One Size Does Not Fit All, 29 AM. REV. InT'L ArB. 429, 450 (2019).

162. Id., cite provisions

163. Id. 
with USMCA for failing to support the United States' energy interests sufficiently. ${ }^{164}$ Because the 2012 treaty does not eliminate any USMCA rules, the non-binding arbitration provided in the 2012 treaty remains an additional remedy for a dispute in the transboundary region. Arbitration under the 2012 treaty may now be more likely to be utilized in the event of a dispute because the options under USMCA are so limited, but its application is also likely to be contested.

USMCA adds an annex to the investor arbitration provision that adds a specific structure to disputes in the energy sector because of the presence of PEMEX. ${ }^{165}$ Annex 14-E creates a neutral forum for licensees to resolve disputes about transactions that a unitization agreement may fall under, but investors receive less protection from expropriation. ${ }^{166}$ Generally, USMCA provides investors less protection than NAFTA, but USMCA makes it more evident than NAFTA that investors in the energy sector can have remedies under the treaty. ${ }^{167}$ These challenges posed by USMCA's dispute resolution provisions make it even more important that the Joint Commission has enough expertise that it can anticipate and prevent any disputes before triggering a dispute resolution procedure.

The infamous "Sunset Clause" in USMCA adds to the uncertainty investors in the transboundary region face. ${ }^{168}$ The Sunset Clause was hotly contested, criticized, and praised during the USMCA negotiations. ${ }^{169}$ The Sunset Clause provides that USMCA will terminate 16 years after entry, but every six years a commission will review USMCA for potential changes, and must affirm each party's

164. Addendum, Letter to Ambassador Lighthizer from Industry Trade Advisory Committee on Energy and Energy Services (Oct. 25, 2018), https://ustr.gov/sites/default/files/files/agreements/FTA/AdvisoryCommitteeReport s/ITAC_6_REPORT-Energy_and_Energy_Services_Addendum.pdf.

165. Martin J. Valasek, Alison G. FitzGerald \& Jenna Anne de Jong, Major changes for investor-state dispute settlement in new United States-Mexico-Canada Agreement, NORTON ROSE FULBRIGHT (Oct. 2018), https:/www.nortonrosefulbright.com/en/knowledge/publications/91d41adf/majorchanges-for-investor-state-dispute-settlement-in-new-united-states-mexico-canadaagreement.

166. Id.

167. Id.

168. Cora Di Pietro, USMCA Sunset Clause Offers Potential Resolution to Ratification Impasse, GLOBAL TrADE (July 1, 2019), https:/www.globaltrademag.com/usmca-sunset-clause-offers-potential-resolutionto-ratification-impasse/.

169. Alan Beattie \& James Politi, How is Donald Trump's USMCA Trade Deal Different from NAFTA? FINANCIAL TIMES (Oct. 1, 2018), https://www.ft.com/content/92e9ce0a-c55f-11e8-bc21-54264d1c4647. 
desire to extend USMCA for another 16 years, or USMCA will terminate upon expiration of the 16 year term. ${ }^{170}$ Interestingly, USMCA also allows a party to withdraw as long as they provide a 6 month notice, adding to the uncertainty. ${ }^{171}$ The Industry Trade Advisory Committee on Energy and Energy Services opposed the clause specifically because it could harm the energy sector's necessarily long-term investments. ${ }^{172}$ As offshore oil and gas projects operate on a long timeline, USMCA could potentially go out of effect by failing to be re-approved between an IOC winning a lease and going into production. This would leave the dispute resolution regime totally uncertain, and clearly deters IOC investment in the transboundary region specifically, and in Mexico generally.

USMCA specifies Mexico's sovereign ownership of hydrocarbons in a stand-alone chapter titled, "The Mexican State's Direct, Inalienable, and Imprescriptible Ownership of Hydrocarbons." ${ }^{173}$ It also specifies that Mexico has a right to reform its domestic law, even though the point has never been disputed. ${ }^{174}$ The chapter specifies the Mexican state's ownership of all hydrocarbons in the continental shelf and EEZ "in strata or deposits, regardless of their physical conditions." 175 This statement does not state anything new about Mexico's hydrocarbon law or state anything inconsistent with international law. Although chapter 8 uses more forceful language, it essentially restates what the United States and Mexico acknowledged in the 2012 treaty.

Because AMLO's administration unlikely has the capacity to roll back Mexico's energy reforms as promised, chapter 8 of USMCA seems mostly symbolic. AMLO's administration can halt the bidding process and renegotiate a few contracts, or if he finds it politically expedient, he can allow all private contracts already negotiated to remain. Keeping the existing contracts and not allowing any more

170. USMCA

art.

34.7 , https://ustr.gov/sites/default/files/files/agreements/FTA/USMCA/Text/34_Final_Pr ovisions.pdf.

171. Di Pietro, supra note 169.

172. Report of the Industry Trade Advisory Committee on Energy and Energy $\begin{array}{lll}\text { Services, } & \text { Sept. 27, }\end{array}$ https://ustr.gov/sites/default/files/files/agreements/FTA/AdvisoryCommitteeReport s/ITAC\%206\%20REPORT\%20-\%20Energy\%20and\%20Energy\%20Services.pdf. 173. United States-Mexico-Canada Agreement, Ch. 8, https://ustr.gov/sites/default/files/files/agreements/FTA/USMCA/Text/08_Recogni tion_of_Mexican_Ownership_of_Hydrocarbons.pdf.

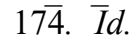

175. Id. 
would have the benefit of allowing PEMEX to gain expertise, an expanding market, and exploration data from the existing contracts while appearing to roll back reforms by merely halting any new contracts. The downside is this will slow the development of the Mexican energy sector because they will not have as much IOC investment. The concerns in both the United States and Mexico reflect how China's trade practices have made national security a larger concern in all trade agreements, with the result of undermining international accountability to global bodies. ${ }^{176}$

USMCA also seems to have been written with an eye to limit Chinese economic ties with North America by giving each nation veto power over free-trade deals. ${ }^{177}$ In the context of the Trump administration's "trade war" with China, some experts have claimed that USMCA strengthened the United States' position negotiating tariffs with China. ${ }^{178}$ AMLO's administration is leveraging the tensions between the United States and China by calling for a "Marshall Plan" investment in Central America - and threatening to get help from Chinese investors if the United States is not on board. ${ }^{179}$ The United States is clearly concerned about growing Chinese influence because their state-directed economy has been able to disrupt global trade flows in their favor. ${ }^{180}$ USMCA Article 32.10 requires any party to the treaty negotiating with a non-market economy (such as China) to notify the other parties of their relationship, provide the parties the opportunity to review any agreements they reach, keep them generally informed, and determine if USMCA will apply to the country with a non-market economy. ${ }^{181}$ This provision is unlikely to prevent Mexico from doing business with Chinese enterprises, but signals that the United States will scrutinize

176. Puig, supra note 129, at 59-60.

177. Lee Jeong-ho, et. al., China 'Threatened with Isolation' by Veto Written into US-Mexico-Canada Trade Deal, South China Morning Post (Oct. 2, 2018, 10:01 PM), https://www.scmp.com/economy/china-economy/article/2166702/chinathreatened-isolation-veto-written-us-mexico-canada-trade.

178. Yen Nee Lee, The US-Mexico Trade Deal May be Bad News for China, CNBC (Aug. 28, 2018, 7:16 AM), https://www.cnbc.com/2018/08/28/the-usmexico-trade-deal-may-be-bad-news-for-china-experts-say.html.

179. Azam Ahmed \& Elisabeth Malkin, Mexico's Strategy for Dealing with Trump: Warn Him About China, N.Y. TIMES (Dec. 17, 2018), https://www.nytimes.com/2018/12/17/world/americas/mexico-migrantstrump.html.

180. Terence P. Stewart \& Shahrzad Noorbaloochi, The USMCA \& United StatesCanada Trade Relations: The Perspective of a U.S. Trade Practitioner, 43 Can.U.S.L.J. 280, 287 (2019).

181. Id. 
any agreement and potentially leverage its position if it sees an operation as a threat. ${ }^{182}$

Additionally, CNOOC - owned by the Chinese government - has spent recent years investing in offshore oil blocks on both sides of the GOM. ${ }^{183}$ Experts believe that CNOOC is investing on both sides of the transboundary region so that it can apply the same principles it learns during unitization negotiations to offshore resources in contested regions of the South China Sea. ${ }^{184}$ The Chinese government will also likely apply what it learns during the unitization negotiations as another tool in consolidating its Belt and Road Initiative ("BRI") to integrate Eurasian economies under a Chinese-led anti-democratic economic system. ${ }^{185}$ A defining feature of the BRI is maximizing flexibility in international law and treaties to favor Chinese ventures. ${ }^{186}$ The 2012 treaty, because of it's vague terms, provides a key learning opportunity for the application of flexibility in international law. Thus, the implications of any decisions the Joint Commission comes to will have considerable influence in coming geopolitical realignments as power projection supplants the regime of international legal bodies established in the $20^{\text {th }}$ century.

\section{CONCLUSION}

The 2012 transboundary treaty was negotiated with a different legal regime and geopolitical framework in mind. Mexico's state-owned venture, PEMEX, was in severe crisis, but free trade agreements like the TPP promised to solve some of its problems while maintaining the national monopoly. Though leaders of both countries foresaw Mexico's energy sector liberalizing, the treaty was designed for a time when there was no IOC exploration in Mexico. Thus, some of the treaty's shortcomings are due to changed circumstances. Going forward, policymakers must consider a legal framework that creates stability so that the rich subsoil hydrocarbons of the GOM are

182. Id.

183. For a short history of Chinese investment in the Gulf of Mexico, see Guillermo Garcia-Sanchez, The Footprint of the Chinese Petro-Dragon: The Future of Investment Law in Transboundary Resources, 94 TULANE L. REV. (forthcoming 2019-2020) (manuscript at 30-34), https://ssrn.com/abstract=3383144.

184. Id. at 50.

185. Ash Milton, China's Belt and Road Plan to Reshape the International Order, PALlADIUM (Oct. 18, 2018), https://palladiummag.com/2018/10/18/chinas-beltand-road-plan-to-reshape-the-international-order/.

186. See Heng Wang, China's Approach to the Belt and Road Initiative: Scope, Character, and Sustainability, 22 J. INT. ECON. L. 29 (Mar. 1, 2019). 
developed efficiently and equitably. This consideration is more vital considering that great power competition is leading States to move away from the oversight of international bodies out of national security concerns.

Ultimately, the treaty's shortcomings would be minimized by an effort to make the Joint Commission more experienced and thus better equipped to negotiate a unitization agreement. Subsidiary committees like the IWBC departments, comprised of members with expertise in maritime boundary disputes, would strengthen the Joint Commission. The Joint Commission can use its existing treaty powers to appoint one or several subsidiary committees to create unitization policy, dispute resolution procedure, set environmental standards, and interpret seismic data. The Joint Commission can increase the expertise and impartiality of the committees by appointing experts in international oil and gas arbitration who have excellent industry knowledge; IBWC members; and respected experts in international law. Expert committees could alleviate the vague environmental and safety standards by creating something more concrete for the Joint Commission to implement that benefits all parties. The committees could also lessen the effect of the treaty's unclear dispute resolution clause, while avoiding a lengthy treaty amendment or renegotiation. Because no committee policy is binding without the Joint Commission's approval, the two Joint Commission members would have a veto that maintains state sovereignty but is more likely to produce effective policies.

Both the United States and Mexico desire to develop offshore oil as safely and efficiently as possible. The 2012 treaty left open the possibility that a light Rule of Capture could be applied if unitization negotiations failed, even though this would likely be contrary to international law. Though not directly in conflict, the interests of the United States, Mexico, and potential IOC licensees are not aligned, so great care is needed to craft a unitization agreement. While allowing a licensee to continue production by putting profits in escrow may be the best option, it may not benefit investors who lose opportunity costs and cash flow while the profit remains in escrow. Because of Medellin and Mexico's USMCA's limited ISDS provisions, investor disputes could be subject to legal challenges in both countries. USMCA's sunset provision creates more uncertainty for investors. If the Joint Commission has the resources to make the best decisions, it will prevent disputes from arising and entering this arena of legal uncertainty surrounding the dispute resolution provisions. 
Most importantly, the Joint Commission delegating its authority to committees can depoliticize much of the decision-making process without undermining executive prerogatives in the treaty. As the world goes through geopolitical realignment and global financial difficulty, Chinese NOC investment in Mexico's offshore oil may provoke a less equitable United States reaction during negotiations. Frosty relations between the United States and China may mean that geopolitical concerns take precedence over economic and energy security concerns. The way the United States and Mexico apply the 2012 treaty will have a direct effect in contested areas around the world, like the South China Sea. Thus, it is imperative that the United States and Mexico behave as good neighbors so they can exploit ocean resources that until recently were considered the property of all humanity by virtue of natural law. 